\title{
Kruszenie muru \\ O wpływie niezależnych ośrodków informacyjnych i wydawniczych na politykę kulturalną PRL
}

\author{
Lawina bieg od tego zmienia, \\ Po jakich toczy się kamieniach, \\ I, jak zwykł mawiać już ktoś inny, \\ Możesz, więc wpłyń na bieg lawiny - \\ Czesław Miłosz, Traktat moralny
}

Miłośnicy filmu potrafią zapewne bez trudu wyliczyć wiele fabuł, w których motywem przewodnim są ucieczki więźniów z pilnie strzeżonych kazamatów. Mnie najbardziej utkwiło w pamięci dzieło Franka Darabonta Skazani na Shawshank z wielkimi rolami Tima Robbinsa i Morgana Freemana. Sam proces rozbijania - a właściwie żmudnego wydłubywania pojedynczych kamieni z grubej warstwy więziennego muru - nie jest tam pokazany. Dopiero w kulminacyjnym momencie, po wykryciu ucieczki niesłusznie skazanego na dożywocie bankiera, strażnicy więzienni znajdują w jego celi - ukrywaną przez lata pod wielkim plakatem Rity Hayworth - wielką dziurę, przez którą, po pokonaniu labiryntów podziemnych tuneli i kanałów, skazaniec wydostał się na wolność. Piękna fasada - a za jej plecami tajemnicza, ale jakże ponętna przestrzeń, do której dotarcie jest możliwe jedynie po pokonaniu licznych niebezpieczeństw i przeszkód.

Sytuacja bohatera wspomnianego filmu, skazanego za niepopełnione winy na dożywocie, przypomina los mieszkańców totalitarnych państw mających do wyboru fatalistyczną, bierną zgodę na zastaną sytuację społeczno-polityczną albo jakąś formę oporu i walki. $Z$ jednej strony dość kruche i niepewne- ale jednak - poczucie bezpieczeństwa, z drugiej zaś wymagająca ryzyka, ale nęcąca przestrzeń wolności, życia ,jak się chce”, możliwości decydowania o własnym losie. Tę swoistą współzależność sformułowaną przez Wernera Heisenberga

* Prof. dr hab., e-mail: tatarowscy@op.pl; Uniwersytet Łódzki, Katedra Dziennikarstwa i Komunikacji Społecznej. 
przypomniał niedawno w znakomitym szkicu Koniec leżenia brzuchem do góry, poświęconym współczesnym europejskim dylematom, dominikanin, ojciec Maciej Zięba, pisząc:

Wolność i bezpieczeństwo podlegają duchowej zasadzie Heisenberga. Im bardziej koncentrujemy się na wolności, tym bardziej rozmywa się nasze bezpieczeństwo, a koncentracja na bezpieczeństwie prowadzi do tego, że coraz „słabej oznaczona” jest nasza wolność. Obrona wolności nieuchronnie dokonuje się kosztem bezpieczeństwa ${ }^{1}$.

\section{Komunikacyjne bariery ${ }^{2}$ i społeczny opór - rekonesans}

Niezwykle ciekawe materiały do śledzenia tych zależności odnajdujemy w historii Polski. Aby nie sięgać zbyt daleko w głąb - do XIX-wiecznych niepodległościowych zrywów powstańczych czy do tragicznej epopei Powstania Warszawskiego - skupię w tym szkicu uwagę na okresie ostatnich kilkudziesięciu lat, kiedy po jałtańskich porozumieniach mocarstw Polska została wpisana do sowieckiej strefy wpływów.

Narzucona całemu społeczeństwu nowa rzeczywistość ,jedynie słusznego systemu społeczno-politycznego", nadzorowanego przez rządzącą partię komunistyczną i jej „zbrojne ramiona” (milicję i wojsko), z wszechmocną cenzurą kontrolującą prawomyślność narzędzi społecznej komunikacji (mediów), stanowiła trudne wyzwanie, szczególnie dla inteligencji twórczej.

Kruszenie prawnych i politycznych barier stojących na straży „,nowego ładu” było procesem długotrwałym i dokonywało się ewolucyjnie, a znaczącą rolę odegrała w nim - nadająca swe audycje radiowe z Monachium od 3 maja 1952 roku - emigracyjna Rozgłośnia Polska Radia Wolna Europa. Jak pisałem, podsumowując jej kulturotwórczą rolę w innym miejscu:

I wrogowie, i przyjaciele stacji upatrywali jej znaczenia przede wszystkim w działalności informacyjnej i politycznej, w antykomunizmie, ale ta etykietka w sposób niepełny odzwierciedlała jej cele i zamierzenia. Program RWE nie sprowadzał się bowiem do „czarno-białego" ideologicznego schematyzmu [...]. Było to zawsze bardziej konsekwencją szerszych założeń ideowo-politycznych niż celem samym w so-

${ }^{1}$ M. Zięba, Koniec leżenia brzuchem do góry, „Rzeczpospolita Plus Minus” 2016, nr 22, 28-29.05, s. 39.

${ }^{2}$ Szerzej na ten temat zob. K.W. Tatarowski, Bariery komunikacyjne i ich rola $w$ dyskursie społecznym w Polsce przed 1989 rokiem, [w:] Komunikatywizm - przyszłość nauki XXI wieku, red. G. Habrajska, Primum Verbum, Łódź 2016, s. 309-320. 
bie. Obiektywna informacja, kształtowanie wzorców obywatelskiego myślenia w oparciu o reguły demokratycznego państwa, ocalanie samoświadomości i substancji narodowej poprzez nawiązywanie do historii, tradycji, zasobów kultury - to były szerokie założenia, realizowane w różnych audycjach, często nic nie mających wspólnego z bieżącą polityką.

I dzięki temu przede wszystkim Rozgłośni Polskiej RWE udało się najpierw podtrzymywać w społeczeństwie polskim i nie dać zgasnąć wątłemu płomykowi nadziei na nadejście lepszych czasów, a następnie wspomagać te inicjatywy i akcje środowiskowe, które przyczyniały się do pozytywnych zmian w różnych sferach życia społecznego. Dzięki tej strategii programowej Głos Wolnej Polski RWE stawał się „radiem zastępczym” i pełnił rolę ,zastępczej opozycji” politycznej - a po jej powstaniu w kraju stał się jej „,tubą nagłaśniającą” oraz partnerem w dialogu³.

W Polsce nasilenie żądań powiększenia zakresu swobód obywatelskich i poszerzania wolności słowa można obserwować od październikowego przełomu w 1956 roku. Już wtedy, a nawet wcześniej, bo w czasie protestów robotniczych w czerwcu 1956 w Poznaniu, doszło do niszczenia urządzeń zagłuszających audycje RWE i wysuwania postulatów zaprzestania zakłócania programu monachijskiej rozgłośni. „Kompletne urządzenie stacji zagłuszającej zachodnie audycje radiowe, które atakujący wyrzucili przez okna budynku, było rozbijane w kawałeczki i rozdeptywane stopami tłumu; działo się to na oczach wojska"4. Najbardziej znienawidzonymi symbolami komunistycznego reżimu - pisał dalej Jan Nowak-Jeziorański - ,było więzienie na Młyńskiej, budynek bezpieki przy ul. Kochanowskiego, zagłuszarka na gmachu Zakładu Ubezpieczeń Społecznych przy ul. Dąbrowskiego"5. Wśród postulatów zgłaszanych na robotniczych wiecach w zakładach pracy w całej Polsce w październiku 1956 roku - obok żądań zwolnienia uwięzionego prymasa kardynała Stefana Wyszyńskiego, przywrócenia religii w szkołach i zawarcia nowego porozumienia z Kościołem - powtarzał się postulat zniesienia zagłuszania rozgłośni radiowych nadających z Zachodu ${ }^{6}$. Jak widać z tych przykładów, potrzeba wolności słowa wyraziście artykułowana była przez wszystkie grupy społeczne w PRL. Również zresztą w późniejszym okresie - wystarczy przypomnieć, że dopuszczenie na ekrany filmu Robotnicy'80 było jednym z postulatów studentów strajkujących w Łodzi zimą 1981 roku.

\footnotetext{
${ }^{3}$ K.W. Tatarowski, Literatura i pisarze w programie Rozgłośni Polskiej Radio Wolna Europa, Universitas, Kraków 2005, s. 299.

${ }^{4} \mathrm{Z}$ relacji SeftonaDelmera, korespondenta gazety „Daily Express”, cyt. za: J. Nowak-Jeziorański, Wojna w eterze, Znak, Kraków 2006, s. 243.

5 Tamże, s. 244.

${ }^{6}$ Szerzej pisze o tym J. Nowak-Jeziorański, tamże, s. 266-273. Zagłuszanie z terenu Polski zostało zniesione 24 XI 1956 roku, ale nadal kontynuowane było z terytorium Czechosłowacji i ZSRR. Przywrócono je w 1971 roku i kontynuowano aż do 1988 roku.
} 
Właściwa walka musiała się jednak rozegrać na polu kultury i sztuki. W dziedzinie kultury październikowy przełom oznaczał znaczne poszerzenie obszaru swobód twórczych i pojawienie się wielu oryginalnych osobowości artystycznych w literaturze, plastyce, muzyce, filmie, teatrze. Ale nadal poza nawiasem oficjalnie akceptowanego kanonu narodowej kultury pozostawali twórcy emigracyjni, którzy nie zgadzali się na cenzorskie interwencje w swoje teksty (a to stanowiło warunek udostępnienia ich dzieł polskim odbiorcom w kraju), nadal istniały tematy tabu, o których mówić i pisać nie było wolno, nadal pełną kontrolę nad publiczną dystrybucją dóbr kultury sprawowała niesuwerenna partia rządząca.

Po 1956 roku powstał też, i rozwinął się w następnej dekadzie, studencki ruch teatralny, muzyczny, plastyczny, literacki, który można by ująć wspólnym terminem „,kultury niezależnej” bądź też „kultury alternatywnej”, związany z młodością, potrzebą buntu, kontestacji, znalezienia własnych środków ekspresji w opozycji do sytuacji zastanej. Operując aluzją, ironią, żartem, sięgał po nowe środki artystycznego wyrazu, nawiązując do zachodnich awangardowych wzorców. Aż do końca lat 60. nie doszło jednak do otwartego buntu skierowanego przeciwko ideologii i polityce kulturalnej komunistycznych władz PRL.

Przełom nastąpił w okresie marcowych wydarzeń w 1968 roku, kiedy doszło do masowych protestów studenckich po zdjęciu ze sceny Teatru Narodowego w Warszawie spektaklu Dziadów Adama Mickiewicza w reżyserii Kazimierza Dejmka. Była to decyzja ówczesnych władz podjęta w klimacie antysemickiej i antyinteligenckiej nagonki. W następstwie tych wydarzeń, a następnie krwawego stłumienia robotniczych strajków na Wybrzeżu w grudniu 1970 roku, ukształtowały się grupy artystyczne - literackie (Nowa Fala, nazywana również Pokoleniem 1968-1970) i teatralne, które, rezygnując z języka aluzji i historycznych analogii, odnosiły się wprost do bieżącej sytuacji społeczno-politycznej, zarówno w wypowiedziach o charakterze satyrycznym (warszawski Salon Niezależnych), jak i w spektaklach nasyconych dramatyzmem, w których sięgano również do tekstów poetyckich swoich rówieśników (Jednym tchem według wierszy Stanisława Barańczaka w poznańskim Teatrze Ósmego Dnia).

Kolejny etap walki o wolne słowo w Polsce wiąże się z powstaniem - po brutalnym stłumieniu robotniczych strajków w Radomiu w czerwcu 1976 roku - różnych grup opozycyjnych, działających jawnie, choć w niezgodzie z ówcześnie obowiązującym w PRL prawem, a także z wykształceniem się zakonspirowanego, funkcjonującego poza zasięgiem cenzury, samofinansującego własną działalność drugiego obiegu wydawniczego. Jak pisał Stanisław Barańczak w artykule Fasada i tyły na początku 1977 roku: „Powstała po prostu nowa alternatywa. Zamiast «kompromis albo milczenie», powiadamy dziś «kompromis albo niezależność», «kompromis albo autentyczność», «kompro- 
mis albo wolność»». I wybieramy to drugie"7. Towarzyszyło temu świadomie podjęte ryzyko - dla twórców wykluczenia poza obficie dotowany, ale kontrolowany przez władze partyjno-państwowe oficjalny obieg dóbr kultury, dla wydawców, drukarzy i kolporterów zaś - represji administracyjno-prawnych, wysokich wyroków sądowych, zwolnień z pracy, konfiskaty mienia ${ }^{8}$. Od powstania drugiego obiegu wydawniczego $-\mathrm{z}$ towarzyszącą mu działalnością edukacyjną (Towarzystwo Kursów Naukowych), artystyczną (niezależnie organizowane koncerty, wystawy, spektakle teatralne), wreszcie medialną (Radio Solidarność) - można już mówić o realnej konkurencji i alternatywie wobec oficjalnego, kontrolowanego przez państwo rynku wydawniczego, o znaczącym naruszeniu monopolu informacyjnego.

W okresie solidarnościowego festiwalu „16 miesięcy wolności” czasopisma i książki wydawane konspiracyjnie można było kupować w lokalach „Solidarności" i Niezależnego Zrzeszenia Studentów, większość prasy i biuletynów związkowych drukowana była bez cenzorskiej kontroli. Nastąpiło wówczas też pewne „odblokowanie” twórczości emigracyjnej. Przyjazd do kraju laureata Nagrody Nobla, Czesława Miłosza, i opublikowanie kilku jego książek w państwowych wydawnictwach miały znaczenie nie tylko symboliczne. Mogło się wydawać, że proces „kruszenia murów”, prawnych i cenzuralnych barier zakończy się sukcesem.

Stan wojenny wprowadzony przez ekipę generała Wojciecha Jaruzelskiego spowodował, że wolne słowo, które wyszło na powierzchnię życia publicznego, z powrotem musiało zejść do podziemia. Ale zatrzymać owej fali wolnościowego zrywu komunistycznym zarządcom PRL już się nie udało. Liczba konspiracyjnie wydawanych czasopism i książek spadła co prawda znacząco w porównaniu

${ }^{7}$ S. Barańczak, Fasada i tyly, „Puls” 1977, nr 2, cyt. za: Puls. Nieregularny kwartalnik literacki nr 13 bis 1977-1981. Antologia tekstów publikowanych na łamach edycji krajowej, kom. red. E. Sułkowska-Bierezin, T. Filipczak, Z. Jaskuła, „Tygiel Kultury” Stowarzyszenie Pisarzy Polskich. Oddział, Łódź 2007, s. 247. Tekst miał być wygłoszony na sesji literackiej w Wenecji, autor nie uzyskał jednak od władz PRL zgody na wyjazd.

${ }^{8}$ Do końca 1969 roku najczęściej powoływano się na art. 23 tzw. małego kodeksu karnego: „Kto rozpowszechnia lub w celu rozpowszechniania sporządza, przechowuje lub przewozi pisma, druki lub wizerunki, nawołujące do popełnienia zbrodni lub pochwalające zbrodnię, lub których treść ma pozostawać tajemnicą wobec władzy państwowej albo które zawierają fałszywe wiadomości, mogące wyrządzić istotną szkodę interesom Państwa Polskiego bądź obniżyć powagę jego naczelnych organów, podlega karze więzienia na czas nie krótszy od lat 3". W nowym kodeksie karnym, który obowiązywał od 1 stycznia 1970 roku owe represyjne postanowienia umieszczono w kilku paragrafach, przy czym limit kar w niektórych przypadkach podniesiono. W art. 273 par. 1 k.k. przewidziano karę do 10 lat więzienia dla sprawcy, „który sporządzając pisma szkalujące, lżące i poniżające władze państwowe oraz zawierające fałszywe informacje, używał druku lub innego środka masowej informacji”; cyt. za: B. Kaliski, Kurierzy wolnego stowa (Paryż-Praga-Warszawa 1968-1970), Instytut Historii PAN, Warszawa 2014, s. $282-285$. 
z okresem legalnej działalności „Solidarności”, ale tylko w 1982 roku ukazało się 786 podziemnych gazet i czasopism oraz 273 książki i broszury9'; w następnym pięcioleciu liczba czasopism nieznacznie spadła, książek i broszur zaś wzrosła.

\section{O modelującej roli niezależnych ośrodków informacyjnych}

Dzięki stworzeniu alternatywnej możliwości artykułowania społecznych oczekiwań i potrzeb można mówić o modelującym wpływie niezależnych ośrodków informacyjno-kulturalnych na media zorganizowane w myśl centralistycznej doktryny prasowej, ukształtowanej według marksistowsko-leninowskich regut ${ }^{10}$. Zjawisko to można obserwować od rozpoczęcia działalności przez Rozgłośnię Polską RWE, a także później, po ukształtowaniu się drugiego obiegu wydawniczego w Polsce.

Jak pisał Nowak-Jeziorański:

Istnienie Wolnej Europy bardzo często stanowiło argument za rozluźnieniem cenzury [podkr. KWT]. W 1952 roku Radio Warszawa nie nadawało kolęd, a przecież najbardziej zaciekły komunista lubi polskie kolędy. My zaś bez przerwy nadawaliśmy kolędy i oczywiście słuchała nas cała Polska. Komuniści szybko zrozumieli, że obraca się to przeciwko nim i już w 1953 r. Polskie Radio rozbrzmiewało kolędami. Zenon Kliszko dokonał trafnego spostrzeżenia, że ,propaganda partyjna nie nadąża za potrzebami życia politycznego, wobec czego zostawia wolne pole przeciwnikowi”. Jerzy Putrament przekonywał, iż dywersyjnym Rozgłośniom sprzyja to, że „nasza prasa nie informuje o wielu faktach politycznych mających bezpośrednie znaczenie dla kraju". W tym samym duchu uskarżał się Sokorski - ówczesny Prezes Komitetu ds. Radia i Telewizji: „Spóźniona informacja lub brak informacji oddaje punkty wrogowi. Polskie Radio informuje o Polsce w sposób jednostronny, włącznie różowy, szwankuje informacja o ostatnich wydarzeniach w kraju i przez to nie jest słuchane". Zwykła konkurencja dziennikarska zmuszała przeciwnika do ograniczenia cenzury i rozszerzała margines wolności słowa ${ }^{11}$.

\footnotetext{
${ }^{9}$ Liczby te podaję za: J. Kamińska [właśc. Chojnacki Wł., Chojnacki W.], Bibliografia publikacji podziemnych w Polsce 13 XII 1981-VI 1986, Éditions Spotkania, Paryż 1988, s. 17, 21.

${ }^{10}$ Omówienie funkcji mediów masowych w różnych systemach społeczno-politycznych m.in. w: T. Goban-Klas, Media i komunikowanie masowe. Teorie i analizy prasy, radia, telewizji i Internetu, Wydawnictwo Naukowe PWN, Warszawa 2001, s. 152-183; M. Kunczik, A. Zipfel, Wprowadzenie do nauki o dziennikarstwie i komunikowaniu, przeł. J. Łoziński, W. Łukowski, Wydawnictwo Naukowe Scholar, Warszawa 2000, s. 43-47 (autorzy używają określenia „,sowiecka teoria prasy”).

${ }^{11}$ J. Nowak-Jeziorański, Strategia i taktyka Radia Wolna Europa, [w:] Fakty, wydarzenia, opinie, Czytelnik, Warszawa 2001, s. 22.
} 
Można też mówić o wpływie monachijskiej rozgłośni na polityczne decyzje komunistycznego establishmentu. Tak na przykład było po cyklu audycji z udziałem Józefa Światły, zbiegłego z PRL wyższego urzędnika Urzędu Bezpieczeństwa - pierwsza z nich została nadana w programie RWE 28 września 1954 roku. Pod koniec listopada 1954, w związku z rewelacjami ujawnionymi przez Światłę, odbyło się posiedzenie Biura Politycznego PZPR, a 7 grudnia zlikwidowano Ministerstwo Bezpieczeństwa Publicznego, aresztowano jednego z szefów UB, Józefa Różańskiego, dwu innych - Anatola Fejgina i Romana Romkowskiego usunięto ze służby. Jan Nowak skomentował: „W następstwie czystki i reorganizacji bezpieki powstał chaos w aparacie represyjnym i znaczne osłabienie terroru. Bariera strachu została poważnie zachwiana"'2.

Przykładem bezpośredniego oddziaływania na społeczeństwo może zaś być - przywołana we wspomnieniach pierwszego dyrektora Rozgłośni Polskiej RWE - krótka i niezapowiedziana wcześniej wizyta wiceprezydenta USA Richarda Nixona w Warszawie w 1959 roku. Przyjechał po wizycie w Moskwie, a krajowe media o jego przybyciu informowały nader zdawkowo, inaczej niż rozgłośnia monachijska, która co godzinę podawała informacje o czasie i trasie jego przejazdu. Efekty przerosły chyba oczekiwania, naocznie zaś przekonał się o tym Nixon, który pisał w swoich wspomnieniach:

Po drodze do miasta spostrzegłem, że przyjęcie w Warszawie będzie jednak inne niż w Moskwie. Po obu stronach szosy widać było gromadki oczekujących ludzi. Nagle poczułem uderzenie w twarz. Nie był to kamień, lecz bukiet róż. Wróciłem się do Oskara Langego i zapytałem, co oznaczają krzyki. - Niech żyje Ameryka - odpowiedział.

Na przedmieściach thum ludzi klaszczących, rzucających kwiatami w nasze samochody. Rósł coraz bardziej. Na śródmieściu tłumy nie mieściły się już na chodnikach, wylewały na jezdnię i zamykały nam drogę. Kilku milicjantów nie było w stanie opanować sytuacji. [...]

Oficjalny zakaz podawania wiadomości o mojej wizycie i godzinie mego przylotu do Warszawy nie osiągnął celu, bo rząd polski nie wziął pod uwagę Radia Wolna Europa. RWE wypełniło zapowiedziami fale eteru i wieść rozeszła się po Warszawie i przedmieściach ${ }^{13}$.

Podobne rezultaty przynosiła działalność drugiego obiegu wydawniczego. O tym, jak to wyglądało w praktyce redakcyjnej państwowych pism, mówił jeden z dyskutantów „Kultury Niezależnej” w rozmowie Koniec kultury PRL:

12 J. Nowak-Jeziorański, Wojna w eterze, s. 218.

${ }^{13}$ Za: tamże, s. 373. 
No, ja to widziałem wspaniale na przykładzie Mieczysława Rakowskiego i jego „Polityki”, kiedy on nieszczęsny siedział nad tekstem, wiedział, że ten tekst powinien wrzucić do kosza i wiedział jednocześnie, że jeżeli to zrobi, to ten tekst ukaże się w prasie podziemnej. I w związku z tym zaczynał kombinować, czy nie lepiej jednak, narażając się i prowadząc rozmaite chytre gry - opublikować go w „Polityce”, szukając takiego czy innego poparcia ${ }^{14}$.

W okresie legalnego istnienia NSZZ „Solidarność” cenzura łagodniała, a w procesie „,detotalizacji” polityki kulturalnej władz uczestniczyły całe grupy społeczne. Wprowadzenie stanu wojennego 13 grudnia 1981 roku zahamowało ten proces, ale go nie powstrzymało. Dalej poza zasięgiem cenzury publikowano podziemne gazety i książki, a poza kontrolą instytucji państwowych pojawiały się spektakle teatralne, dzieła filmowe, wystawy plastyczne, koncerty muzyczne, przenosząc się do kościołów i pomieszczeń parafialnych bądź do lokali prywatnych. Partyjno-państwowy monopol informacyjny i wydawniczy został poważnie naruszony. Mur jeszcze stał, ale jego fundamenty zostały znacznie osłabione. $\mathrm{Na}$ istotną, podstawową przyczynę tego stanu rzeczy wskazał jeden z uczestników cytowanej wyżej dyskusji, przeprowadzonej w 1984 roku:

Ja bym przy okazji wrócił do pytania, czy nam się po 13 grudnia zmienił ustrój i ja bym powiedział, że się zmienił. Myślę nawet, że zmienił się troszeczkę wcześniej, a to w tym sensie, że w tym kraju przez ileś tam lat nie istniało coś takiego, jak opinia publiczna. I od któregoś momentu zaistniała. Nawet zachowania samej władzy zaczęły być oceniane, komentowane i jawne. Na początku działo się to za pomocą prasy podziemnej, z okresu 1976-1980, także przez radio. Potem apogeum tej historii to jest okres „Solidarności”. Trzynasty grudnia tej sprawy zaistnienia opinii publicznej nie zmienił, tego czołgami generał nie zlikwidował i nie zlikwiduje ${ }^{15}$.

I tu - jak się wydaje - tkwi rzeczy sedno. Działania, które w wielkim skrócie przypomniałem, nie odbywały się w społecznej próżni. I to je różni w zasadniczy sposób od „cichej prywatnej wojny” wytoczonej represyjnemu systemowi przez uciekiniera z twierdzy Shawshank. Choć metoda działania poprzez żmudne i pracowite kruszenie muru w obu sytuacjach okazała się skuteczna.

\section{Bibliografia}

Barańczak S., Fasada i tyły, „Puls” 1977, nr 2, s. 11.

Goban-Klas T., Media i komunikowanie masowe. Teorie i analizy prasy, radia, telewizji i Interne$t u$, Wydawnictwo Naukowe PWN, Warszawa 2001.

\footnotetext{
${ }^{14}$ Koniec kultury PRL-u (dyskusja), „Kultura Niezależna” 1984, nr 2, s. 30.

15 Tamże, s. 31.
} 
Kaliski B., Kurierzy wolnego słowa (Paryż-Praga-Warszawa 1968-1970), Instytut Historii PAN, Warszawa 2014.

Kamińska J. [właśc. Chojnacki W., Chojnacki W.], Bibliografia publikacji podziemnych w Polsce 13XII1981-VI 1986, Éditions Spotkania, Paryż 1988.

Koniec kultury PRL-u (dyskusja), „Kultura Niezależna” 1984, nr 2, s. 30-31.

Kunczik M., Zipfel A., Wprowadzenie do nauki o dziennikarstwie i komunikowaniu, przeł. J. Łoziński, W. Łukowski, Wydawnictwo Naukowe Scholar, Warszawa 2000.

Nowak-Jeziorański J., Strategia i taktyka Radia Wolna Europa, [w:] Fakty, wydarzenia, opinie, Czytelnik, Warszawa 2001.

Nowak-Jeziorański J., Wojna w eterze, Znak, Kraków 2006.

Tatarowski K.W., Bariery komunikacyjne i ich rola $w$ dyskursie spolecznym w Polsce przed 1989 rokiem, [w]: Komunikatywizm - przyszłość nauki XXI wieku, red. G. Habrajska, Primum Verbum, Łódź 2016, s. 309-320.

Tatarowski K.W., Literatura i pisarze w programie Rozgłośni Polskiej Radio Wolna Europa, Universitas, Kraków 2005.

Zięba M., Koniec leżenia brzuchem do góry, „Rzeczpospolita Plus Minus” 2016, nr 22, 28-29.05, s.12.

Konrad W. Tatarowski

\section{The crumbling of the wall. About the influence of independent information hubs and publishing hubs on the cultural politics of PRL}

\section{(Summary)}

The author of the article reminds us about the most important phases of the fight for freedom of speech in Poland between 1945 and 1989, during the time when the country was under Soviet influence. It indicates a broad public support of the activities of Radio Free Europe, which broadcast its programmes from Munich as well as support for various independent artistic and publishing initiatives in the country during that time. It also indicates the influence of independent information and cultural hubs on those media that were organised in a central doctrine according to marksist-leninist rules.

Keywords: The Polish Section of Radio Free Europe; independent culture in People's Republic of Poland; „second circulation” publishing in Peoples Republic of Poland; the social role of the independent media. 